\title{
Studies on the diversity of ciliate species in Gahai Alpine Wetland of the Qinghai-Tibetan Plateau, China
}

\author{
H. C. Liu ${ }^{1,2}$, X. J. Pu${ }^{1}$, J. Liu ${ }^{1}$ and W. H. Du¹,3 \\ ${ }^{1}$ College of Grass Science of Gansu Agricultural University, Lanzhou, Gansu Province 730070 China \\ 2 Department of Chemistry and Life Science of Gansu Normal University for Nationalities, Hezuo, Gansu Province \\ 747000 China \\ ${ }^{3}$ Correspondence to Du Wen-hua,duwh@gsau.edu.cn, Present address: No. 1, Yingmen village, Anning District, \\ Lanzhou, Gansu province, China
}

Keywords: Ciliate, Community structure, Distribution, Functional-trophic group, Gahai Alpine Wetland of Qinghai-Tibetan Plateau, Species diversity.

\begin{abstract}
This study investigated the community structure of ciliates in Gahai Alpine Wetland of Qinghai-Tibetan Plateau, China. We hypothesized that the ciliate community in the Plateau is more complex and the species diversity is richer than those in other climate zones of China. In particular, we studied how the ciliate species responded to environmental temperature, soil moisture content and the manner of pasture utilization. We determined key features of the ciliate communities such as trophic functional groups, ciliate seasonal distribution, species diversity and similarity index at six sample sites from January 2015 to October 2016. To count and characterize ciliates, we combined the non-flooded Petri dish method with in vivo observation and silver staining. We identified 162 ciliate species in this area, showing a high species and functional diversity. The mode of nutrition was diverse, with the lowest number of ciliates in group $\mathrm{N}$ (Nonselective omnivores, 4 species) and the highest number in group B (Bacterivores-detritivores, 118 species, corresponding to $73 \%$ of the total species number). Ciliate species richness was significantly positively correlated with environmental temperature and moisture and adversely related to the intensity of agricultural land use. Rotational grazing by livestock or suspended grazing might be useful for maintaining good soil quality, thereby favoring ciliate diversity. Our study may serve as a reference to evaluate the ecosystem status of the Gahai Alpine Wetland and other similar areas in future studies.
\end{abstract}

Abbreviation: GAW- Gahai Alpine Wetland.

\section{Introduction}

Wetlands are unique ecological systems because they have the features of both land and water. Wetlands are not only an important environment for human survival, but also ecological landscapes with rich biodiversity. These systems provide a variety of social, economic, and ecological functions, such as resisting flood, regulating runoff, improving climate and maintaining ecological balance, which cannot be replaced by other systems (Zhang and Zhang 2012). However, global warming, overgrazing, and increasing of human population and industrialization have caused wetland resources to be seriously exploited and damaged, resulting in daily decrease of their ecological functions (Cheng et al. 2009, Zhao et al. 2009). Therefore, wetlands have received a great deal of attention from scholars and governments worldwide. The concept of wetland protection and utilization has also transferred from protecting "waterfowl habitats" to protecting the ecological, social and economic functions provided by wetlands, especially the functions for providing fresh water resources and controlling flood, drought and environmental pollution (Yang 2002).

Gahai Alpine Wetland (GAW) is located in the northeastern margin of the Qinghai-Tibetan Plateau, the upstream of the Yellow River, China and has a typical alpine climate and an average altitude of $3400 \mathrm{~m}$. The GAW is characterized by a long winter, from November to March of the following year, and short warm season (from June to August) (Fan et al. 2011). It provides winter pastures for livestock to graze in the long winter. The GAW is very important to the water conservation and recharge, and its ecological stability affects the industrial and agricultural production and social development of the middle and lower reaches of the Yellow River. Once the wetland system is damaged, the biodiversity across the whole basin would decline; lakes and rivers in the lower reaches might shrink, dry up, or become saline rapidly. These further aggravate the deterioration of regional ecological environment and pose a serious threat to human survival (Chen et al. 2007, Yang et al. 2015). Therefore, protecting the GAW is of national and regional ecological security.

In order to protect the GAW wetland ecosystems properly, it is useful to study the structure of wetland communities. In recent years, the community studies of alpine wetlands have transferred from plant and flora to large animals. Scholars have paid more and more attention to the microbial function of wetland systems (Lee and Chang 2016, Li et al. 2016, Ren et al. 2013). Because of their small size, high reproductive rate and sensitivity to environmental changes, protozoa be- 
come increasingly popular for scholars to study the stability of the wetlands (Jiang et al. 2011). Ciliates comprise one of the most important protozoan groups in wetlands. Ciliate abundance, species diversity and richness have been shown to correlate with nutrient, salinity or temperature of wetlands (Wu et al. 2015, Xu et al. 2016, Jiang et al. 2011). They are commonly used as bioindicators in the water habitat due to rapid response to the change of environmental conditions (Foissner and Berger 2015). Besides, ciliates could live in the soil. Thus, the characteristics of ciliate community could be used to monitor not only the aquatic environment but also the terrestrial habitats (Lara 2012). Physico-chemical parameters and ciliate community structure of surface sediment collected from two constructed mangrove belts were used as a good bioindicator in assessing organically polluted sediment qualities and revealed that the efficiency of better sewage treatment was higher in the Aegiceras than that of Sonneratia (Chen et al. 2008). By now, there was no such study in the GAW.

We hypothesized that the ciliate community is more complex and the species diversity is richer than those in other climate zones of China. Therefore, we studied how the ciliate species responded to environmental temperature, soil moisture content and pasture utilization to prove whether ciliates could be used as bioindicator to assess the quality of GAW. We determined key features of the ciliate communities in GAW such as trophic functional groups, ciliate seasonal distribution, species diversity and their similarity at six sample sites from January 2015 to October 2016. Our study may serve as a reference to evaluate the ecosystem status of GAW and other areas in future studies.

\section{Materials and methods}

\section{Experimental area and sample setting}

Sampling was carried out at National Nature Reserve on the northeastern edge of the Qinghai-Tibetan Plateau (Fig. 1). This wetland stretches across the Yangtze and Yellow Rivers and serves as the habitat and breeding ground for many rare birds because of its abundant water and grass resources. Sampling areas in this study varied from $3473.8 \mathrm{~m}$ to 3493.7 $\mathrm{m}$ a.s.1., where water and soil temperature ranged from $-1{ }^{\circ} \mathrm{C}$ in winter to $30^{\circ} \mathrm{C}$ in summer. Six sampling sites (Fig. 1) were used in this study: No. 1, the water of Gahai Lake; No. 2, a typical swamp near Gahai Lake; No. 3, a degraded marsh in the northeast corner of Gahai Lake; No. 4, a degraded marsh in the northwest corner of Gahai Lake; No. 5, a path for livestock to drink water in the southeast corner of Gahai Lake, where the vegetation has been seriously degraded due to long-term trampling of livestock; No. 6, a marsh in the southeast corner of Gahai Lake. The position, altitude, temperature, and moisture contents at the six sites varied (Table 1).

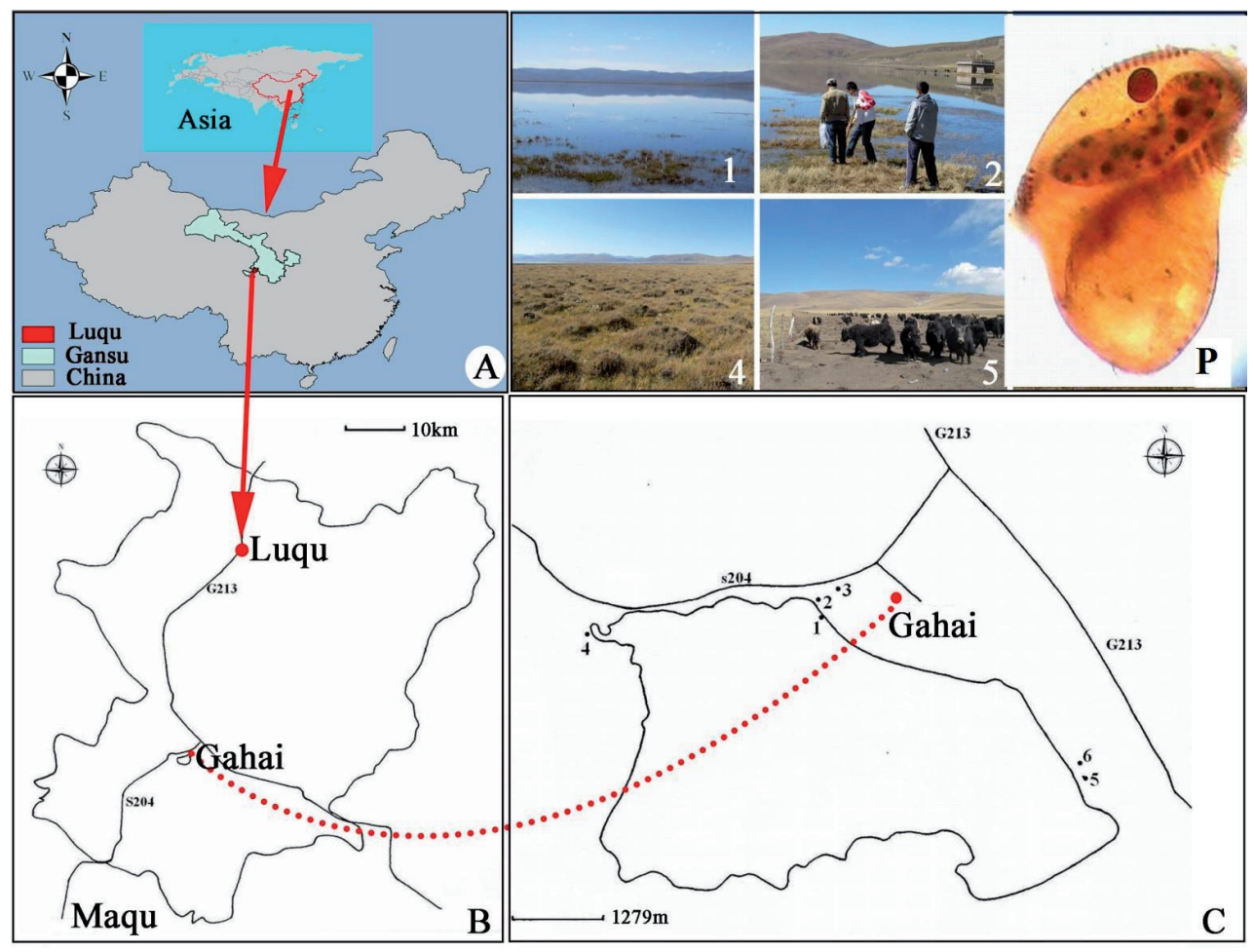

Figure 1. Sampling sites. (A) Geographic position of Asia, China and Gansu province. (B) The location of the GAW in Luqu County. (C) Sampling sites in the GAW. The sampling site 1, 2, 4, and 5 are labeled with numbers (1, 2, 4 and 5, respectively) and dark dots, and shown as pictures above; P: Metopus gibbus after protargol impregnation. Gahai: Gahai Alpine Wetlands (GAW). The doted red line indicates the sampling sites of Gahai Alpine Wetland belong to Luqu County, Gansu Province, China, and Asia. 
Table 1. Characteristics of the environmental factors of sampling sites.

\begin{tabular}{|c|c|c|c|c|c|}
\hline Time of sampling & Sites & Location & $\begin{array}{l}\text { Altitude } \\
\text { (m) }\end{array}$ & Temperature $\left({ }^{\circ} \mathrm{C}\right)$ & Moisture content (\%) \\
\hline \multirow{4}{*}{ Jan 2015 (Winter) } & 1 & E $102^{\circ} 20^{\prime} 28^{\prime \prime}$, N $34^{\circ} 14^{\prime} 35^{\prime \prime}$ & 3478.3 & -0.5 & 100.0 \\
\hline & 3 & E $102^{\circ} 20^{\prime} 30^{\prime \prime}, \mathrm{N} 34^{\circ} 14^{\prime} 44^{\prime \prime}$ & 3478.8 & -0.5 & 20.4 \\
\hline & 4 & E $102^{\circ} 18^{\prime} 20^{\prime \prime}, \mathrm{N} 34^{\circ} 14^{\prime} 21^{\prime \prime}$ & 3493.7 & -0.3 & 26.8 \\
\hline & 6 & E $102^{\circ} 23^{\prime} 12^{\prime \prime}, \mathrm{N} 34^{\circ} 13^{\prime} 12^{\prime \prime}$ & 3476.1 & -0.5 & 32.3 \\
\hline \multirow{4}{*}{ April 2015 (Spring) } & 1 & & & 14.2 & 100.0 \\
\hline & 2 & & & 13.5 & 73.4 \\
\hline & 3 & & & 16.0 & 21.8 \\
\hline & 4 & & & 11.8 & 29.5 \\
\hline \multirow{5}{*}{ July 2015 (Summer) } & 2 & & & 18.0 & 48.7 \\
\hline & 3 & & & 25.0 & 7.1 \\
\hline & 4 & & & 20.0 & 26.1 \\
\hline & 5 & & & 30.0 & 6.9 \\
\hline & 6 & & & 24.8 & 44.4 \\
\hline \multirow{4}{*}{ October 2015 (Autumn) } & 1 & & & 4.8 & 100.0 \\
\hline & 2 & & & 5.0 & 40.4 \\
\hline & 3 & & & 4.1 & 20.7 \\
\hline & 4 & & & 8.0 & 29.9 \\
\hline
\end{tabular}

\section{Sample collection}

At site 1, water samples from the upper $(20 \mathrm{~cm}$ to surface), middle ( $40 \mathrm{~cm}$ to $60 \mathrm{~cm}$ ) and bottom layers (near the sediment-water interface) of Gahai Lake were collected using a water sampler ( $2 \mathrm{~L}$ in capacity). The samples were then mixed, stored in plastic bottles and placed at room temperature $\left(25^{\circ} \mathrm{C}\right)$ until subsequent microscopic examination.

At sites 2, 3, 4, 5, and 6, samples were randomly collected from each site underground at a depth of 5-10 $\mathrm{cm}$ from an area of $400 \mathrm{~m}^{2}$ using the 5-point-sampling-method (Lu et al. 2017) and a $15 \mathrm{~mL}$ cylindrical sampler. Materials collected included top-soil with fine plant roots, humic layer, and deciduous and/or grass litter from the soil surface. Five samples collected from the same site were then mixed, and brought to laboratory to determine the moisture content and for microscopic analysis. Additionally, soil temperature and geographic coordinates of each site (Table 1) were determined using the curved soil thermometer and GPS, respectively (Dou et al. 2015).

\section{Determination of the soil moisture content}

The moisture contents of soil samples were determined using the traditional drying method ( $\mathrm{Li}$ et al. 2009). The remaining samples were air-dried and sealed in paper bags for later microscopic analysis.
Cultivation of soil samples

The water samples collected from site 1 were examined directly; however, the soil samples were cultivated for 2 or 3 days with the non-flooded Petri dish method before microscopic examinations (Foissner 1997, Lee and Soldo 1992, Liu et al. 2012). Briefly, the soil samples were spread over the bottom of a Petri dish, and then slightly over-saturated with distilled water. After 2 days, the soil suspension was used for microscopic examinations.

\section{Microscopic examination}

According to the method described by Foissner et al. (2002), the samples were investigated several times from different positions of the Petri dish until no new species could be observed. Each rewetted sample or water sample was observed in vivo. After being shaken evenly, one drop of the soil suspension was placed on a glass slide and the features including body shape, size, movement mode, and the position and number of contractile vacuoles were observed under a bright field microscope with the low $(10-40 \times)$, middle $(40 \times)$, and high-power objective $(100 \times)$ (Foissner 1991). For some fast-swimming specimens, the Vaseline Cover Glass Method was used to reveal their detailed features. For some new or assumed new ciliate species that were difficult to determine in vivo, silver staining methods such as Wilbert' protargol and silver carbonate were used (Foissner 2014). Ciliate identifi- 
Table 2. Taxonomic status of Ciliophora (Protozoa) in GAW.

\begin{tabular}{|c|c|c|c|c|c|c|}
\hline Phylum & Class & Order & & Family & Genus & Species \\
\hline \multirow{16}{*}{ Ciliophora } & \multirow{6}{*}{ Kinetofragminophorea } & Prostomatida & & 11 & 14 & 31 \\
\hline & & Pleurostomatida & & 2 & 2 & 5 \\
\hline & & Colpodida & & 5 & 7 & 25 \\
\hline & & Nassulida & & 2 & 4 & 9 \\
\hline & & Cyrtophorida & & 1 & 1 & 6 \\
\hline & & Suctorida & & 1 & 1 & 2 \\
\hline & Subtotal & & 6 & 22 & 29 & 78 \\
\hline & \multirow{3}{*}{ Oligohymenophorea } & Hymenostomatida & & 6 & 8 & 12 \\
\hline & & Scuticociliatida & & 3 & 4 & 13 \\
\hline & & Peritrichida & & 1 & 1 & 8 \\
\hline & Subtotal & & 3 & 10 & 13 & 33 \\
\hline & \multirow{4}{*}{ Polyhymenophorea } & Heterotrichida & & 4 & 4 & 13 \\
\hline & & Tintinnida & & 1 & 1 & 1 \\
\hline & & Oligotrichida & & 2 & 2 & 3 \\
\hline & & Hypotrichida & & 7 & 17 & 34 \\
\hline & Subtotal & & 4 & 14 & 24 & 51 \\
\hline \multicolumn{2}{|l|}{ Total } & & 13 & 46 & 66 & 162 \\
\hline
\end{tabular}

cation was conducted based on the literature (Agatha 2004, Berger 1999, Berger and Foissner 1989, Dixon 1937, Feng et al. 2004, Finlay et al. 2000, Foissner 1995 1997, 2003, 2014, Foissner and Al-Rasheid 1999, Hardoim and Heckman 2010, Johnson and Ward 1997, Jung et al. 2016, Lee et al. 2000, Ning and Shen 1999, Patterson 1992, Wickham et al. 2000 2004).

\section{Calculation of the similarity of ciliate assemblages}

The similarity of ciliate assemblages was calculated using the Jaccard coefficient (Jaccard 1908), $J=c /(a+b-c)$, where $a$ is the total number of species at site A, $b$ is the total number of species at site $\mathrm{B}$, and $c$ is the number of species present in both sites.

\section{Analysis of the functional groups of ciliates}

The ciliate species found in the GAW were divided into four functional groups based on their feeding strategy, Algivores (A), Bacterivores-detritivores (B), Predators and Raptors (R), and Nonselective omnivores (N) (FernandezLeborans and Fernandez-Fernandez 2002, Pratt and Cairns 2010, Shen et al. 1990).

\section{Correlations}

Correlations between the number of ciliate species, temperature, and moisture content were analyzed using the Pearson Correlation Analysis of binary variables in SPSS19.0 (Patvardhan et al. 2011).

\section{Results}

\section{Community structure of ciliates}

Based on the ciliate classification system provided by Lynn (2008), we found 162 ciliate species, including 30 uni- dentified ones, at the six sample sites in the GAW. They belong to 66 genera, 46 families, 13 orders and 3 classes (Table 2), among which, 78 species are in Kinetofragminophorea and belong to 29 genera, 22 families, and 6 orders accounting for $48.2 \%$ of the total number of ciliates; followed by Polyhymenophorea, which contains 51 species and belong to 24 genera, 14 families and 4 orders. Finally, there were 33 species in Oligohymenophorea with 13 genera, 10 families, and 3 orders. Additionally, we found that the order Hypotrichida was the dominant group with 34 species and accounted for $21.0 \%$ of the total number of ciliates in the GAW, followed by Prostomatida (31 species) which accounted for $19.1 \%$. There were $25,13,13,5,9,6,2,12,8$, 3 , and 1 species that belong to Colpodida, Heterotrichida, Scuticociliatida, Pleurostomatida, Nassulida, Cyrtophorida, Suctorida, Hymenostomatida, Peritrichida, Oligotrichida, and Tintinnida, respectively. There were also 30 unidentified ciliate species, which account for $18.5 \%$ of the species that observed in the samples of the GAW.

\section{Trophic functional groups of ciliates in the GAW}

The feeding habits of ciliates were complex. Some species only ingest one kind of food, while others feed on many types of food (Foissner 1998). As shown in Supplementary Material, Table A1, group B (Bacterivores-detritivores) was dominant with 118 species and $72.8 \%$ of the total number of ciliate species in the samples of the GAW. These species ingest algae, fungi and debris. There were 51 species in group A (Algivores), which only feed on algae. The number of ciliates in group R (Predators and Raptors) and N (Nonselective omnivores) was 18 and 4, respectively.

\section{Distribution of ciliate species}

Distribution of ciliates at six sites. As shown in Supplementary Material, Table A1, the number of ciliates at sites 1 and 2 was 
Table 3. Pearson correlation between the number of ciliate species and the moisture content and temperature.

\begin{tabular}{|c|c|c|c|c|}
\hline & & Number of ciliate species & Temperature & Moisture content \\
\hline \multirow{3}{*}{ Number of ciliate species } & Pearson correlation & 1 & $0.429^{*}$ & $0.414^{*}$ \\
\hline & Sig. (two tails) & & 0.036 & 0.044 \\
\hline & $\mathrm{N}$ & 24 & 24 & 24 \\
\hline \multirow{3}{*}{ Temperature } & Pearson correlation & & 1 & -0.104 \\
\hline & Sig. (two tails) & & & 0.628 \\
\hline & $\overline{\mathrm{N}}$ & & & 24 \\
\hline \multirow{3}{*}{ Moisture content } & Pearson correlation & & & 1 \\
\hline & Sig. (two tails) & & & \\
\hline & $\mathrm{N}$ & & & \\
\hline
\end{tabular}

*Indicates the correlation is significant at the 0.05 level.

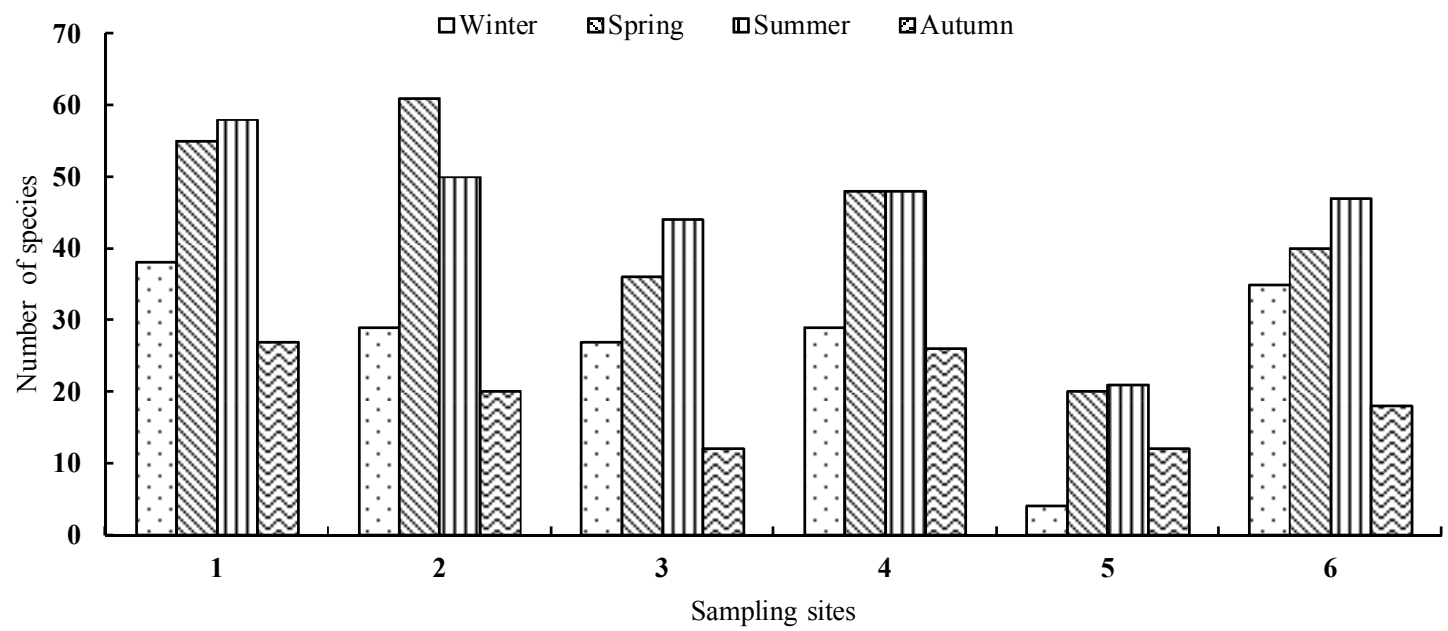

Figure 2. Seasonal distributions of ciliates at sampling sites.

greater than those of the other sites. The lowest number of ciliate species was found at site 5. Sites 4 and 6 were similar in the number of ciliates.

Based on the frequency of ciliate species found at each site, 14 dispersed species appeared at six sites, while 45 common species were observed at site 4 and 5 , and 39 rare species only occurred at one site (Supplementary Material, Table A1).

Seasonal distribution of ciliates. The seasonal distribution of ciliates was shown in the last line of Supplementary Material, Table A1. More ciliate species appeared in autumn and summer, while only a few were observed in spring and winter. These findings demonstrate that more ciliates choose warm conditions.

Effect of the interaction between sites and seasons on ciliates distribution. As shown in Figure 1, the number of ciliate species peaked at site 2 in summer, and it was also high at site 1 in autumn and summer. In contrast, there were few ciliates found at site 5 in spring.

The seasonal frequency of 162 ciliate species at the six sites (Supplementary Material, Table A1) showed that four species (Leptopharynx eurystoma, Colpoda inflata, Halteria grandinella and Gonostomum affine) occurred with frequen- cies greater than $71 \%$. Cyclidium citrullus, Cyclidium versatile and Colpoda steinii were common species at six sites and 50 species were present with frequencies from $25 \%$ to 68\%. Thirty-three species, including Actinobolina radians, Dileptus conspicuous, and Dileptus anser et al. appeared only at site 1 during winter or spring.

Correlations of ciliate species number with moisture content and temperature

Pearson correlation analysis of the number of ciliate species, moisture content and temperature of the sampling sites (Table 3) showed that the number of ciliate species was positively correlated with the moisture and temperature at an alpha level of 0.05 . This result is consistent with the distribution of ciliate species at sites and seasons as shown in Supplementary Material, Table A1 and Figure 2.

\section{Similarity of ciliate assemblages}

Similarity among four seasons and six sites. The average similarity coefficient of ciliate species among four seasons was 
the highest (0.40) in winter and the lowest (0.10) in autumn (the last line in Supplementary Material, Table A2). The similarity coefficient was also high in summer. For the six sites, the average similarity coefficient of ciliate species ranged from 0.09 to 0.31 , the highest value was found between site 6 and 2, and the lowest was between site 1 and 5 (the last 5 columns in Supplementary Material, Table A2).

Similarity of ciliate species among six sites during different seasons. As shown in Supplementary Material, Table A2, the similarity coefficients of ciliate species varied greatly among sites and seasons. Specifically, the similarity coefficient of ciliate species among sampling sites ranged from 0.00 (between site 5 and 1 in autumn) to 0.20 (between site 3 and 6 in autumn), while in spring it ranged from 0.03 (between site 1 and 3 ) to 0.30 (between site 5 and 6). However, during summer and winter, these values ranged from 0.15 (between site 3 and 6) to 0.45 (between site 1 and 2), and 0.20 (between site 1 and 5, and site 2 and 5) to 0.63 (between site 3 and 6), respectively.

Similarity of ciliate species between GAW and the other typical climate zones of China. The similarity coefficient of ciliate species between GAW and other six typical zones (middle torrid zone of Jianfengling, Hainan province; northern torrid zone of Xishuangbanna, Yunnan province; subtropical zone of Luojiashan, Wuhan province; warm temperate zone of Xiaolongmen, Beijing; temperate zone of Changbaishan, Jilin province and high frigid zone of Haibei, Qinghai province) (Ning and Shen 1998) in China indicated that ciliate species in the GAW were very dissimilar from the other typical climate zones of China, and that the similarity coefficient varied from 0.08 to 0.18 (Supplementary Material, Table A3).

\section{Discussion}

Alpine wetland ecosystems are easily affected by human activities (Li et al. 2010). Degradation of alpine wetlands leads to wetland shrinking, biodiversity decline, and desertification, which can cause serious ecological disasters (Wu 2015). Due to their small size, short life cycle, cosmopolitan distribution, and rapid response to environmental changes, protozoa have been widely used as bio-indicators to monitor the quality of aquatic environments (Jiang et al. 2007, Kiss et al. 2009, Payne 2013). Moreover, ciliates play an important role in nutrient cycling, energy flow, and food webs (Gaedke and Straile 1994), and participate in the maintenance of the ecological balance (Suzuki and Miyabe 2007). Therefore, it is very important to study the features of the ciliate community structure, trophic functional groups of ciliates, and species distribution characteristics. The results from such study could help to evaluate the ecological condition of the GAW, understand factors affecting the number of ciliate species, and provide a basic reference for environmental protection organizations in the GAW.

\section{Community structure of ciliates}

Wetlands are unique ecological systems composed of both aquatic and terrestrial elements, which make them suit- able for both aquatic and terrestrial species to live in. In the GAW of the Qinghai-Tibetan Plateau, Hypotrichida ciliates were the dominant group because of their flat body, which enables them not only to swim in water, but also to crawl over soil granules or nearby litter materials (Ning and Shen 1998). This finding is consistent with the results reported by Ba et al. (2014), Li et al. (2010), and Ma et al. (2009). Prostomatid ciliates could easily obtain enough food from aquatic and terrestrial habitats because of their anterior oral apparatus (Guhl et al. 1996); therefore, many Prostomatid ciliates were found in the GAW. In addition, 25 Colpodida species occurred in the GAW because they had strong ability to adapt to the environment could easily encyst when moisture levels decreased, and then excyst while the soil was rewet (Foissner et al. 2002).

When compared to the results of ciliate species observed in the plateau swamp wetlands of Maqu County (Ning, et al. 2014ab, Ning, et al. 2013ab) and the Lehalu wetland (Basang 2013) of the Qinghai-Tibetan Plateau, abundant ciliate resources existed in the GAW and the community structure of ciliates in this area was much more complex. Taken together, these findings demonstrate that the ecosystem in the GAW was more stable than that of other wetlands.

\section{Trophic functional groups of ciliates in the GAW}

Ciliates can rapidly respond to environmental changes, and the trophic functional groups of ciliates can be used to appraise water environmental quality (Calvodíaz et al. 2011). Protozoa can be divided into four trophic-functional groups (Algivores, Bacterivores-detritivores, Predators and Raptors, Nonselective omnivores) based on their feeding strategies (Shen et al. 1990). Higher number of Algivores and Bacterivores-detritivores is associated with better water environmental quality (Shen et al. 1990). In this study, the trophic-functional groups of ciliates from water and soil in the GAW showed that many ciliates belonged to these two groups (A and B) (Supplementary Material, Table A1), indicating that the environmental quality of water and soil in the GAW was good.

\section{Distribution of ciliate species}

Water is known to be an important factor affecting the survival and distribution of protozoa (Liao et al. 2003, Tian 2012). Water and temperature affected the distribution of ciliates, and the moisture content of samples was the main factor influencing ciliates distribution (Mieczan and TarkowskaKukuryk 2014). In this study, the number of ciliate species in the GAW was positively correlated with moisture (Table 3 ). A large number of ciliates was distributed at sites 1 and 2 because site 1 is the water of Gahai Lake; site 2 is on the edge of the lake and could be easily submerged in summer and many ciliates may be transferred to this area while the water level is elevated. In contrast, because site 5 was trampled by livestock for a long time, the soil was dense and bare, and the average moisture content was low (Table 1); subsequently, the lowest number of ciliates was found in this area (Supplementary Material, Table A1). Site 3 was in a degraded marsh in which 
the ground coverage and average soil moisture content were low, so there was a small number of ciliate species in this area (Supplementary Material, Table A1).

Temperature was also an important factor influencing the distribution of ciliates (Mieczan and Tarkowska-Kukuryk 2014). A high density of ciliates was found in warmer parts of the year (Bojanić et al. 2001). In this study, ciliate density was positively correlated with temperature (Table 3 ) and more ciliate species were observed in summer and autumn in the GAW (Supplementary Material, Table A1). These findings indicate that ciliates prefer a habitat with suitable warm temperatures such as during summer and autumn, and abundant moisture such as at sites 1 and 2 .

Grazing influenced the distribution of ciliates ( $\mathrm{Jrb}$ et al. 2005). Long-term or heavy grazing can reduce ground coverage and make the surface bare, leading to the loss of water and ciliates in the soil surface (Mieczan and Tarkowska-Kukuryk 2014). Pastures in the GAW were used for grazing livestock from November to May of the following year; therefore, the number of ciliates was the lowest in winter, followed by spring. At site 5, the number of ciliate species was the smallest in winter and spring because of long-term trampling of livestock during this period, while their numbers increased during the rest of the year (Supplementary Material, Table A1). In contrast, many ciliates were found at site 6 because of grazing rest in this area (Table 1). Therefore, rest-rotation grazing could be a useful way to elevate the number of ciliates and improve the environment (Jrb et al. 2005).

Ciliate distribution was the results of several factors (Jiang et al. 2014) and highly selective to habitats (Ricci 1989). In addition to the water, temperature, and grazing condition, distribution of the ciliate species was also influenced by the amount of food resources (Fenchel 1990). As we know, ciliates could encyst when the environmental conditions are unfavorable and it would also affect ciliate distribution and diversity investigated in GAW.

Frequency is an important parameter and reflects the spatial distribution of ciliate species, as well as the adaptability and selectivity of ciliates to the environment (Zhou et al. 2011). As shown in Supplementary Material, Table A1 fewer ciliate species could adapt to the changeable climate, water and soil conditions of the GAW; therefore, only 15 ciliate species appeared at all sites throughout the season. This result is in accordance with those of Bartosova and Tirjakova (2008) and Zhou et al. (2011), who found that ciliate species were subject to strong climate selection. In this study, the ciliate species observed at five sites were defined as the widespread species, ciliates appeared at two to four sites were the common species, and species that occurred only at one site as the rare species. As shown in Supplementary Material, Table A1, 42 species were widespread and more than $83 \%$ belonged to group B because of their feeding habits. Of which, Colpoda cucullus, Colpoda inflata, Cyclidium versatile and Leptopharynx eurystoma were found at 4 sites and 15 species such as Gonostomum affine, Cyclidium citrullus, Colpoda maupasi et al. was found in more than 2 sites. It suggests that these species could tolerate low tem- peratures and were mainly distributed in shallow soils. Among 40 rare species, Tintinnidium fluviatile, Coleps bicuspis, and Vorticella cupifera only occurred in water, while Colpoda tripartita, Hemisincirra sp., and Paracolpoda sp. only appeared in the terrestrial habitats.

\section{Similarity of ciliate assemblages}

Overall similarity and biodiversity of a community are important parameters and reflect the complexity and stability of communities and the ecological or environmental quality (Ning and Shen 1998). The similarity among sites can reflect the degree of spatial heterogeneity to a certain extent, and sites with high similarity coefficient values may have similar ecological conditions or nutrients needed by ciliates (Weisse 2006). Conversely, vegetation and environmental factors had significant effects on protozoan communities, and sites with different vegetation and environmental conditions had low similarity (Vargas and Hattori 1990). In the present study, the average similarity coefficients of the four seasons and six sites were low, which explains the abundant diversity of ciliate species across sites and seasons. That few ciliate species were found at different sites during winter might be due to their strong cold-tolerant ability and therefore the similarity coefficients were high. Equally, the high temperature and moisture content, as well as the rest-rotation grazing resulted in that many ciliate species exist during autumn and summer. As the species diversity increased, the similarity coefficient decreased (Vargas and Hattori 1990). The similarity coefficient also reflected the effects of environmental factors on ciliate community composition (Li et al. 2008). Areas with similar environments, such as sites $3,4,5$, and 6 in winter, had relatively high similarity coefficients. In addition, the similarity coefficient of ciliate species between the GAW and six habitats of China showed that the community composition of ciliates in the GAW varied greatly. Even in different habitats of the same area, such as the highly frigid zone of Haibei, Qinghai province, the faunal composition of ciliates also differed significantly because of their small niches (Ricci 1989).

\section{Conclusions}

In the GAW of the Qinghai-Tibetan Plateau, ciliates had diversified forms of nutrition. The community structure of ciliates was stable and the quality of water and soil in this area was good. The community composition of ciliates was highly spatially heterogeneous in the GAW. Ciliate species in this area were extremely dissimilar from the other areas of China. A large number of ciliate species was found in aquatic habitats and terrestrial environments because they have not been subjected to too much anthropogenic disturbance. Restrotation grazing might help to maintain the quality of the GAW.

Acknowledgements: We appreciate Prof. Jing-Jiang Zhou of JJ Scientific Consultant Ltd, UK for proofreading. This work was supported by 'The Project of Sustainable Development 
and Innovation Team of Grassland and Livestock in Gansu Province (2017C-11), National Natural Science Foundation of China (31760702, 313600577), and National Key R and D Program of China (2018YFD0502402-3).

\section{References}

Agatha, S. 2004. A cladistics approach for the classification of Oligotrichid ciliates (Ciliophora: Spirotricha). Acta Protozool. 43(3):201-217.

Ba, S., Huang, X., Pu, B. and Ma, Z.X. 2014. Community characteristics of ciliates and water environment evaluation in Lhalu wetland during summer and autumn. Chinese J. Ecol. 33(10): 2740-2748

Bartosova, P. and Tirjakova, E. 2008. Diversity and ecology of ciliates (Alveolata: Ciliophora) living in the bark and decaying wood mass in Slovakia. Acta Protozool. 47(3):173-187.

Basang. 2013. Study on the characteristics of community structure of Protozoa, Lhasa Lhalu wetland National Nature Reserve, Tibet. Master Thesis, Northwest Normal University, Lanzhou.

Berger, H. 1999. Monograph of the Oxytrichidae (Ciliophora, Hypotrichia). Springer, Dordrecht, The Netherlands.

Berger, H. and Foissner, W. 1989. Morphology and biometry of some soil hypotrichs (Protozoa: Ciliophora). Bull. Brit. Mus. (Natural History) 55:19-46.

Bojanić, N., Šolić, M., Krstulović, N., Marasović, I., Ninčević, Ž. and Vidjak, O. 2001. Seasonal and vertical distribution of the ciliated protozoa and micrometazoa in Kaštela Bay (central Adriatic). Helgoland Mar. Res. 55(2):150-159.

Calvodíaz, A., Díazpérez, L., Suárez, L.Á., Morán, X.A., Teira, E. and Marañón, E. 2011. Decrease in the autotrophic-to-heterotrophic biomass ratio of picoplankton in oligotrophic marine waters due to bottle enclosure. Appl. Environ. Microb. 77(16):5739-5746.

Chen, Q.H., Xu, R.L., Tam, N.F.Y., Cheung, S. G. and Shin, P. K. S. 2008. Use of ciliates (Protozoa: Ciliophora) as bioindicator to assess sediment quality of two constructed mangrove sewage treatment belts in Southern China. Mar. Pollut. Bull. 57(6):689-694.

Chen, Y.N., Li, W.H., Chen, Y.P., Xu, C.C. and Zhang, L.H. 2007. Water conveyance in dried-up river way and ecological restoration in the lower reaches of Tarim river, China. Acta Ecol. Sinica 27(2):538-545

Cheng, X., Liu, H.C., Du, H.F., Wang, H.J. and Ning, Y.Z. 2009. Species diversity of sarcodinids and flagellates in the provincial nature reserve of wetland of first meander of Yellow River. $J$. Northw. Norm. Univ. 45(6):92-97.

Dixon, A. 1937. Soil protozoa; their growth on various media. Ann. Appl. Biol. 24(2), 442-456.

Dou, Y.J., Chang, L. and Wu, D.H. 2015. Research methods of soil animal food web: A review. Chinese J. Ecol. 34(1):247-255.

Fan S.R., Fan G.Z., Dong Y.P. and Zhou D.W. 2011. Research of the seasonal division method of Tibetan Plateau. Plat. Mount. Meteorol. Res. 31(2):1-12.

Fenchel, T. 1990. Adaptive significance of polymorphic life cycles in Protozoa: responses to starvation and refeeding in two species of marine ciliates. J. Exp. Mar. Biol. Ecol. 136(3):159-177.

Feng, W.S., Yang, J., Ye, Z.H., Miao, W., Yu, Y.H., Huang, M.H. and Shen, Y.F. 2004. Soil protozoa in wetland treatment system of $\mathrm{Pb}-\mathrm{Zn}$ mine in Fankou. Chinese J. Zool. 39(1):2-11.

Fernandez-Leborans, G. and Fernandez-Fernandez, D. 2002. Protist functional groups in a sublittoral estuarine epibenthic area. Estuaries 25(3):382-392.
Finlay, B.J., Black, H.I.J., Brown, S., Clarke, K.J., Esteban, G.F., Hindle, R.M. and Vickerman, K. 2000. Estimating the growth potential of the soil protozoan community. Protist 151(1):69-80.

Foissner, W. 1991. Basic light and scanning electron microscopic methods for taxonomic studies of ciliated protozoa. Eur. J. Protistol. 27(4):313-330.

Foissner, W. 1995. Tropical protozoan diversity: 80 ciliate species (Protozoa, Ciliophora) in a soil sample from a tropical dry forest of Costa Rica, with descriptions of four new genera and seven new species. Arch. Protistenkund. 145(s 1-2):37-79.

Foissner, W. 1997. Global soil ciliate (Protozoa, Ciliophora) diversity: a probability-based approach using large sample collections from Africa, Australia and Antarctica. Biodivers. Conserv. 6(12): $1627-1638$.

Foissner, W. 1998. An updated compilation of world soil ciliates (Protozoa, Ciliophora), with ecological notes, new records, and descriptions of new species. Eur. J. Protistol. 34(2):195-235.

Foissner, W. 2003. Morphology and ontogenesis of Lambornella trichoglossa nov. spec., a new tetrahymenid ciliate (Protozoa, Ciliophora) from Brasilian tank bromeliads (Bromeliaceae). Eur. J. Protistol. 39(1):63-82.

Foissner, W. 2014. Basic light and scanning electron microscopic methods for taxonomic studies of ciliated protozoa. Int. J. Sys.t Evo.l Microbiol. 27(4):271-292.

Foissner, W., Agatha, S. and Berger, H. 2002. Soil ciliates (Protozoa Ciliophora) from Namibia (Southwest Africa), with emphasis on two contrasting environments, the Etosha Region and the Namib Desert. PART I: text and line drawings. Denisia 5:1-1459.

Foissner, W. and Al-Rasheid, K.A.S. 1999. Updating the trachelocercids (Ciliophora, karyorelictea). VI. A detailed description of Sultanophrys arabica nov. gen., nov. spec. (Sultanophryidae nov. fam.). Eur. J. Protistol. 35(2):146-160.

Foissner, W. and Berger, H. 2015. A user-friendly guide to the ciliates (Protozoa, Ciliophora) commonly used by hydrobiologists as bioindicators in rivers, lakes, and waste waters, with notes on their ecology. Freshwater Biol. 35(2):375-482.

Gaedke, U. and Straile, D. 1994. Seasonal changes of the quantitative importance of protozoans in a large lake: An ecosystem approach using mass-balanced carbon flow diagrams. Marine Microbial Food Webs 8:163-188.

Guhl, B.E., Finlay, B.J. and Schink, B. 1996. Comparison of ciliate communities in the anoxic hypolimnia of three lakes: general features and the influence of lake characteristics. J. Plankton Res. 203(3):335-353.

Hardoim, E.L. and Heckman, C.W. 2010. The seasonal succession of biotic communities in wetlands of the tropical wet-and-dry climatic zone: IV. The free-living sarcodines and ciliates of the pantanal of Mato Grosso, Brazil. Int. Rev. Hydrobiol. 81(3):367384.

Jaccard, P. 1908. Nouvelles recherches sur la distribuition florale. Bul.l Soc. Vaud. Sci. Nat. 44(163):223-270.

Jiang, J.G., Wu, S.G. and Shen, Y.F. 2007. Effects of seasonal succession and water pollution on the protozoan community structure in a eutrophic lake. Chemosphere 66(3):523-532.

Jiang.Y., Xu, H.L., Hu, X.Z., H., Zhu, M.Z., Al-Rasheid, K.A. and Alan, W. 2011. An approach to analyzing spatial patterns of planktonic ciliate communities for monitoring water quality in Jiaozhou Bay, northern China. Mar. Poll. Bull. 62(2):227-235.

Jiang, Y., Yang, E.J., Sun, Y.K., Kim, Y.N. and Lee, S.H. 2014. Spatial patterns in pelagic ciliate community responses to various habitats in the Amundsen Sea (Antarctica). Prog. Oceanogr. 128:49-59. 
Johnson, M.D. and Ward, A.K. 1997. Influence of phagotrophic protistan bacterivory in determining the fate of dissolved organic matter (DOM) in a wetland microbial food web. Microb. Ecol. 33(2):149-162.

Jrb, T., Rook, A.J. and Rutter, S.M. 2005. Impact of grazing management on biodiversity of grasslands. Ani. Sci. 81(2):193-198.

Jung, J., Park, K. and Kim, S. 2016. Morphology and molecular phylogeny of the soil ciliate Anteholosticha rectangula sp. nov. from King George Island, Maritime Antarctica. Acta Protozool. 2:89-99

Kiss, Á. K., Ács, É., Kiss, K.T. and Török, J.K. 2009. Structure and seasonal dynamics of the protozoan community (heterotrophic flagellates, ciliates, amoeboid protozoa) in the plankton of a large river (River Danube, Hungary). Eur. J. Protistol. 45(2):121-138.

Laraa, E. 2012. A molecular perspective on ciliates as soil bioindicators. Eur. J. Soil Biol. 49(2):107-111.

Lee, J. and Chang, C.Y. 2016. A new species of the genus Bryocamptus (Copepoda, Harpacticoida, Canthocamptidae) from alpine wetlands at Jeju Island, Korea, P. Biol. Soc. Wash. 32(3):219-229.

Lee, J.J., Leedale, G.F. and Bradbury, P. 2000. An illustrated guide to the Protozoa: Organisms traditionally referred to as Protozoa, or newly discovered groups. Volume I (2nd ed.). Society of Protozoologists, Lawrence, Kansas.

Lee, J.J. and Soldo, A.T. 1992. Protocols in protozoology. J. Am Diet. Assoc. 104:35-35.

Li, G.W., Wang, Y.J., Luo, J.M. and Wang, Z.L. 2009. Research on the soil moisture content of Zhalong wetland during thawing period. J. Sci. Teach. Coll. Univ. 29(6):71-74.

Li, H.L., Yu, K.L., Ratajczak, Z., Nippert, J.B., Tondrob, D., Xu, D. H., Li, W. and Du, G.Z. 2016. When variability outperforms the mean: trait plasticity predicts plant cover and biomass in an alpine wetland. Plant Soil 407(1-2):1-15.

Li, J., Liao, Q., Li, M., Zhang, J., Tam, N.F. and Xu, R. 2010 Community structure and biodiversity of soil ciliates at Dongzhaigang Mangrove Forest in Hainan Island, China. Appl. Environ. Soil Sci. 2010, 1-8.

Li, J.Q., Lin, X.F., Xu, H.L. and Song, W.B. 2008. Characterization of the community structure of periphytic ciliates in intensive marine shrimp-farming pond and response to environment factors. Acta Hydrob. Sinica 32(4):493-500.

Liao, C.H., Li, J.X., Yang, Y.P. and Zhang, Z.C. 2003. The community of soil animals in tropical rain forest in Jianfeng Mountain, Hainan Island, China: Relationship between seasonal change of community structure and climatic factors. Acta Ecol. Sinica 23(1):139-147.

Liu, H.C., Ma, L., Min, X.M., An, L.L., Sang, J. C., Ma, X.R. andMin, X.L. 2012. Analysis of community structure and functional-trophic group of protozoa in Gahai Lake in winter. Ecol. Sci. 31(6):631-635.

Lu, J.J., Dong, J.M., Ren, M.F., Li, X., Wu., Y.P., Li, D.Q. and Ma, E.B. 2017. Migration patterns of subterranean pest insects in the soil of winter wheat-summer corn rotation fields in Linfen, Shanxi. Acta Entomol. Sinica 60(9):74-87.

Lynn, D.H. 2008. The Ciliated Protozoa. Characterization, Classification, and Guide to the Literature. Springer, New York.

Ma, Z.X., Qin, J., Liu, Y.B. and Ning, Y.Z. 2009. Community characteristics of soil ciliates in scenic spots and historic sites of Pingliang Kongtongshan. J. Northw. Norm. Univ. 45(3):93-99.

Mieczan, T. and Tarkowska-Kukuryk, M. 2014. Ecology of moss dwelling ciliates from King George Island, Antarctic: the effect of environmental parameters. Pol. Polar Res. 35(4):609-625.
Ning, Y. and Shen, Y.F. 1999. New records of protozoa (Sarcomastigophora) in China. Chinese J. Zool. 34(4):2-5.

Ning, Y.Z., Liu, G.L., Dang, H. and Sun, J. 2014a. Community characteristics of ciliates in plateau swamp wetland of Gannan, Gansu in winter. J. Anhui Agri. Sci. 42(4):1059-1062.

Ning, Y.Z. and Shen, Y.F. 1998. Soil protozoa in typical zones of China: II. Ecological study. Acta Zool. Sinica 44(3):271-276.

Ning, Y.Z., Su, C., Wang, H.J., Du, H.F. and Wang, F.G. 2013 a. Community characteristics of ciliates in the plateau swamp wetlands of Gannan, Gansu Province in summer. J. Northw. Norm. Univ. 49(3):81-86.

Ning, Y.Z., Wang, F.G., Du, H.F., Wang, H.J. and Su, C. 2013 b. Ciliate species diversity and its relationships with environmental factors in plateau swamp wetlands of southern Gansu Province, Northwest China in autumn. Chinese J. Ecol. 32(3):634-640.

Ning, Y.Z., Wu, W.N., Liu, H.C. and Chen, L.Y. 2014b. Community characteristics of ciliates in Plateau Swamp Wetland of Gannan in spring. J. Northw. Norm. Univ. 50(2):87-92.

Patterson, D.J. 1992. Free-living freshwater protozoa: a color guide. AMS Press, Washington DC.

Patvardhan, E., Heffernan, K.S., Ruan, J., Hession, M., Warner, P., Karas, R.H. and Kuvin, J.T. 2011. Augmentation index derived from peripheral arterial tonometry correlates with cardiovascular risk factors. Cardiol. Res. Prac. 2011(3):253-258.

Payne, R.J. 2013. Seven reasons why protists make useful bioindicators. Acta Protozool. 52:105-113.

Pratt, J. and Cairns, J., Jr. 2010. Functional groups in the Protozoa: roles in differing ecosystems. J. Eukaryot. Microbiol. 32(3):415423.

Ren, G.H., Deng, B., Shang, Z.H., Hou, Y. and Long, R.J. 2013. Plant communities and soil variations along a successional gradient in an alpine wetland on the Qinghai-Tibetan Plateau. Ecol. Eng. 61(61):110-116

Ricci, N. 1989. Microhabitats of ciliates: Specific adaptations to different substrates. Limnol. Oceanogr. 34(6):1089-1097.

Shen, Y.F., Zhang, Z.S., Gong, X.J., Gu, M.R., Shi, Z.X. and Wei, X.Y. 1990. Modern biomonitoring techniques using freshwater microbiota. Chinese Architecture and Building Press, Beijing.

Suzuki, T. and Miyabe, C. 2007. Ecological balance between ciliate plankton and its prey candidates, pico- and nanoplankton, in the East China Sea. Hydrobiologia 586(1):403-410.

Tian, J.Y. (2012). Impact factor of growth and distribution of protozoa. Nat. Sci. J. Harbin Norm. Univ. 28(4):61-63.

Vargas, R. and Hattori, T. 1990. The distribution of protozoa among soil aggregates. Fems Microbiol. Lett. 74(1):73-77.

Weisse, T. 2006. Freshwater ciliates as ecophysiological model organisms - lessons from Daphnia, major achievements, and future perspectives. Arch. Hydrobiol. 167(4):371-402.

Wickham, S., Gieseke, A. and Berninger, U. G. 2000. Benthic ciliate identification and enumeration: An improved methodology and its application. Aquat. Microb. Ecol. 22(1):79-91.

Wickham, S.A., Nagel, S. and Hillebrand, H. 2004. Control of epibenthic ciliate communities by grazers and nutrients. Aquat. Microb. Ecol. 35(2):153-162.

Wu, F., Huang, J., Dai, M.M., Liu, H. and Huang, H. 2015. Ciliates as bioindicator to monitor different aquatic environments in. Can. J. Zool. 94(4):265-273.

$\mathrm{Wu}, \mathrm{S} . \mathrm{Q}$. 2015. The problem and strategy of restoring ecological function of degraded urban wetland. Guangzhou Environ. Sci. $2: 10-12$. 
Xu, H., Jiang, Y. and Xu, G. 2016. Bioassessment of water quality status using a potential bioindicator based on functional groups of planktonic ciliates in marine ecosystems. Mar. Poll. Bull. 110(1):409-414.

Yang, J.F., Lei, K., Khu, S., Meng, W. and Qiao, F. 2015. Assessment of water environmental carrying capacity for sustainable development using a coupled system dynamics approach applied to the Tieling of the Liao River Basin, China. Environ. Earth Sci. 73(9):5173-5183.

Yang, Y.X. 2002. Main characteristics, progress and prospect of international wetland science research. Prog. Geogr. 21(2):111-120.

Zhang, X.L. and Zhang, F.R. 2012. Preliminary analysis on protection an ecological evaluation system of Yellow River Delta Wetland. Appl. Mech. Mater. 5:178-181.

Zhao, R.F., Chen, Y.N., Zhou, H.R., Li, Y.Q., Qian, Y.B. and Zhang, L.H. 2009. Assessment of wetland fragmentation in the Tarim River basin, western China. Environ. Geol. 57(2):455-464.

Zhou, M., Chung, Y.H., Beauchemin, K.A., Holtshausen, L., Oba, M., Mcallister, T.A. and Guan, L.L. 2011. Relationship between rumen methanogens and methane production in dairy cows fed diets supplemented with a feed enzyme additive. J. Appl. Microb. 111(5):1148-1158.

Received November 14, 2018 Revised February 17, May 7, 2019 Accepted May 11, 2019

\section{Supplementary material}

Table A1. Seasonal distribution and functional-trophic groups of ciliate species in six sampling sites of the GAW.

Table A2. Similarity coefficients of ciliate assemblages for different seasons and sites.

Table A3. Similarity coefficients between the GAW and other sampling sites in different zones of China, based on ciliate species.

The files may be downloaded from www.akademiai.com. 